\title{
Liquidity Ratio Analysis, Profitability Ratio, Leverage Ratio, And Cash Flow Operations To Predict The Financial Distress In Manufacturing Companies Listed In Indonesia Stock Exchange (2015-2018)
}

\author{
Ika Yustina rahmawati ${ }^{1}$, Tiara Pandansari ${ }^{2}$, Fanny Lafyfatun Khasanah ${ }^{3}$ \\ \{rahmawatiraham2015@gmail.com ${ }^{1}, \underline{\text { tiarapandansari@gmail.com², fannylafyfatun@gmail.com }{ }^{3} \text { \} }}$ \\ Lecturer the Faculty of Economy and Business, Universitas Muhammadiyah Purwokerto ${ }^{12}$ \\ Student Faculty of Economy and Business, Universitas Muhammadiyah Purwokerto ${ }^{3}$
}

\begin{abstract}
This research was aimed to find out determine the effect of liquidity ratios, profitability ratios, leverage ratios, and operating cash flow in predicting financial distress in manufacturing companies listed on the Indonesia Stock Exchange (2015-2018). Liquidity ratio, profitability ratio, leverage ratio, and operating cash flow as independent variables, while financial distress as independent variables The object used in manufacturing companies, the sample of 105 companies. Logistic regression analysis was used for the technique analysis of the data. The results showed that the ratio of liquidity and operating cash flow did not influence in predicting financial distress while the other two variables namely profitability ratios and leverage ratios had a very strong influence in predicting financial distress.
\end{abstract}

Keywords: liquidity, profitability, leverage, operating flow, financial distress

\section{Introduction}

The study of the financial statements of a company is primarily because it needs to know the level of profitability (profit) and a company's level of risk or healthy. The simplest task in financial analysis is to evaluate the ratio of financial statements.

Financial reports are prepared to provide details about the financial situation, results, and improvements to the company's financial condition. This is useful for economic decision making. To be able to determine the ability of the organization to produce cash (and cash equivalents), and the time and assurance of the results, information about the financial condition, efficiency, and adjustments in the financial position is required. Controlled resources, financial structure, liquidity, solvency, and ability to adapt to environmental changes affect the company's financial condition. Those are the factors that affect the company's financial condition.

Now, Indonesia has become the largest manufacturing base of ASEAN industries with a contribution of $20.27 \%$ in the national economy. The development of the manufacturing industry in Indonesia is currently able to shift the role of commodity-based to manufacture-based. The government is trying to transform the economy so that it is more focused on the process of developing non-oil and gas industries. The Ministry of Industry also noted several sectors that had a percentage of performance above the national GDP, including the base metal industry at $9.94 \%$, the textile and apparel industry at $7.53 \%$, and the transportation equipment industry at $6.33 \%$. This is also influenced by the purchasing power of the people towards various types of products that are increasing so that the production process will increase according to demand (BKPM/www.investindonesia.go.id).

On the other hand On average, in 10 years Indonesia's economic growth was recorded at just $5.7 \%$ and industrial growth at $5 \%$. The average industrial growth is low compared to economic growth. This reduces the role of the manufacturing sector in the gross domestic product (GDP) by a percentage reaching $22 \%$ in 2014 from $29 \%$ in 2009. Exports of manufactured products are decreasing. Meanwhile, the manufacturing industry trade balance deficit peaked in 2012 with a figure of US \$ 23 billion, although in 2014 it was reduced to the US $\$ 6.4$ billion in line with falling imports. The weakening of the manufacturing industry that has been chronic should be taken seriously. The decline in the industrial sector is inseparable from weakening factors supporting industrial competitiveness. Indonesia's weak competitiveness in the manufacturing industry is also inseparable from the still low level of technological mastery. Grouped by the Organization for Economic Co-operation and Development (OECD), around $66 \%$ of all industrial products are low and medium-low technology. (www.kemenperin.go.id)

Economic conditions that are always experiencing changes have affected the activities and performance of companies, both small and large companies so that many companies went bankrupt, especially some manufacturing companies on the IDX (Indonesia Stock Exchange). Companies that experience bankruptcy are 
measured through their financial statements. Information on financial statements must be converted so that the financial information presented will be more useful in making economic decisions. [11]

Financial distress is a condition of a company experiencing financial difficulties. Other terms of financial distress are bankruptcy, inability to pay off debts, and default. Insolvency in bankruptcy shows negative net worth. Negative performance and liquidity problems are seen from the inability to pay off debt. Default means a company violates agreements with creditors and can lead to legal actions.

This research is a replication study that will be conducted to re-examine the factors in previous studies that affect financial distress. Based on research from), it stated that the liquidity ratio has negative results, the company will be in financial distress. Different results were done in the research.[9] which gave the result that liquidity had a negative effect harmed the company's financial distress. For profitability ratios also have different results from previous studies, the other research shows that the profitability variable has a significant effect on financial distress prediction. The value of profitability (ROA) is large, the more likely the company will experience financial distress. This phenomenon is a phenomenon where economic conditions are unstable.

Different results obtained in the study, the profitability ratio has a significant effect on corporate financial distress. This condition indicates that the economic condition is stable. This study aims to examine and determine the effect of liquidity ratios, profitability, financial leverage, and operating cash flow on the financial distress conditions of manufacturing companies on the IDX.

Based on the above background, the research formulation is as follows: do liquidity, profitability, leverage and cash flow influence the prediction of financial distress? Regarding the formulation of the problems that are formed, it is hoped that this research will have a contribution to the parties involved, namely decision-makers such as internal parties /company management, investors and, financial analysts who can understand the actions to be taken. So that the investment strategy that is carried out does not meet mistakes and is right on target and can provide new insights about science in the financial sector, especially regarding analysis methods in financial reports, the most important thing is the information generated from the analysis to be used by parties in need.

\section{Literature Review}

\subsection{Capital Market}

Classically, the notion of the capital market is a business field of trading securities such as stocks, bonds, and securities, as one of the economic actors, the aspect of obtaining optimal profits is the goal that animates the capital market as a securities trading institution [16]. As was briefly stated in the introduction, that the capital market performs two main functions namely the economic function and financial function. In carrying out its economic function, the capital market makes it easy to transfer funds from lenders to debtors. The second function of the capital market is to carry out financial functions in which the capital market provides the funds needed by borrowers and lenders to provide funds without having to be directly involved in the ownership of real assets needed for such investments.[7]. Capital market activities in Indonesia officially begin in the year 1977. In its development can not be separated from fluctuating economic and monetary conditions. In an efficient capital market condition, a positive relationship between risk and expected return is expected [7].

\subsection{Financial Ratios}

This ratio is an analysis tool that can provide a way out and describe symptoms (symptoms that appear) a situation. In connection with the decisions taken by the company, this ratio analysis aims to assess the effectiveness of the decisions that have been taken by the company in the course of carrying out its business activities. To be able to assess the effectiveness of the three decisions, which in turn can obtain information about the company strengths and weaknesses, the analysis of financial statements need to be directed at the five areas of analysis as follows: Liquidity ratio, Activity Ratio, Solvency Ratio, Profitability Ratios, Ratio Market. The five ratios want to see the company's risk prospects in the future. The prospect factor in the ratio will influence investor expectations of companies in the future.

\subsection{Financial Distress}

The financial condition of a company that is in an unhealthy state is the definition of financial distress. Financial difficulties occurred before the company went bankrupt. Models need to be developed because of financial distress by knowing the financial distress of the company is expected to be taken early measures to anticipate this that led to the bankruptcy. The prediction of the company's financial distress is the concern of many parties. The parties using the model include: 
1. Lenders. Research related to the prediction of financial distress has relevance to lending institutions, both in deciding whether to provide a loan and determining policies to monitor loans that have been given.

2. Investors. Investors when assessing the possibility of a company's problems in repaying principal and interest by using the financial distress prediction model.

3. Regulators. Regulatory bodies have the responsibility of overseeing the ability to pay debts and stabilize individual companies. This causes the need for a model that can be applied to understand the company's ability to pay debts and assess the company's stability.

4. Government. The prediction of financial distress is also important for the government and antitrust regulation.

5. Auditor. The financial distress prediction model can be a useful tool for auditors in making a going concern assessment of a company.

6. Management If the company goes bankrupt, the company will bear the direct costs (accountants and attorneys' fees) and indirect costs (sales losses or forced losses due to court decisions). So with the financial distress prediction model, it is expected that companies can avoid bankruptcy and automatically can also avoid direct and indirect costs of bankruptcy.

\subsection{Hypothesis}

The results of the analysis of financial ratio analysis to the prediction of financial distress are referred to from several previous studies which include different measurements of each financial ratio so that from various references in previous studies, the following hypotheses are formed:

The liquidity ratio is a tool to measure the company's short-term liquidity ability by looking at the company's current assets against its current debt. The liquidity ratio has two short-term liquidity ratios, the current ratio and the quick ratio (acid test ratio). Measuring the company's ability to meet its short-term debt using current assets. Current assets are a business cycle where the assets will turn into cash at one time. Based on previous studies conducted by several researchers include Widiati and Merkusiwati [18], [19] the results of the variable liquidity ratio effect in predicting financial distress.

H1: The effect of the liquidity ratio on the financial distress condition of manufacturing companies listed on the IDX

The level of sales, assets, and capital market is measured by profitability ratios. At the level of sales of high-profit margins mean a company's ability to generate profits will be higher. There are three kinds of ratios, namely: profit margin, return on total assets (ROA), and return on equity (ROE). In a study conducted by Yustika, Kirmizi, Silfi [19], [11], stated that the profitability ratio variable influenced in predicting financial distress.

\section{H2: The effect of profitability ratios on the financial distress condition of manufacturing companies listed on}

\section{the IDX}

Measure the company's ability to meet its long-term obligations using the leverage ratio. Companies that are not solvable are companies whose total debt is greater than total assets. This ratio focuses on the right side of the balance sheet. Measuring the long-term liquidity of a company, another definition of the leverage ratio. Several studies have been conducted where the results of this leverage ratio variable influence predicting financial distress, namely the results of research conducted by [10], [1].

H3: The effect of the leverage ratio on the financial distress condition of manufacturing companies listed on the IDX

Operating cash flow is part of the company's cash flow that represents the amount of cash generated or used by the company from all its activities in a certain period. The results of research from [1], [18] stated that the variable operating cash flow of the company influences in predicting financial distress.

H4: The effect of operating cash flow on the financial distress of manufacturing companies listed on the IDX

\section{Methodology}

Manufacturing companies that are on the Indonesia Stock Exchange for the 2015-2018 period are the population in this study. A purposive sampling method was used as a sampling selection, the sample of the research technique with certain considerations. So that the selected company becomes a research sample that meets the following criteria:

1. Manufacturing companies are on the Indonesia Stock Exchange for the period 2015 - 2018. 
2. The company submits financial statements on December 31 regularly for 3 years by the research period required for the period 2015 to 2018 (the financial statements as of December 31 are audited financial statements).

3. The company does not conduct mergers and acquisitions.

4. The company has a negative net income (net income) for two or more years in a row. This criterion shows the condition of financial distress because having a negative net income for two or more years in a row means the company has experienced a decline in financial conditions or losses. Companies that are used as model validation are companies that tend not to experience financial distress (marked by the absence of negative net income) for two or more years in a row).

Companies are included in the group of companies listed on the Indonesia Stock Exchange obtained from the website http://www.idx.co.id, Indonesian Capital Market Directory (ICMD) 2015-2018, stockok.com, and various other media sources. Secondary data is a source of research data obtained indirectly through intermediary media (obtained and recorded by other parties).

The following operational definitions of the variables are listed in Table 6.1 below:

Table 6.1 Definition of Operational Variables

\begin{tabular}{|l|l|l|}
\hline \multicolumn{1}{|c|}{ Variable } & \multicolumn{1}{|c|}{ Definition } & \multicolumn{1}{|c|}{ Measurement } \\
\hline Financial Distress & $\begin{array}{l}\text { Companies that tend not to financial distress } \\
\text { (marked by the absence of negative net income) for } \\
\text { two or more years in a row) and companies } \\
\text { experience financial distress (characterized by the } \\
\text { occurrence of negative net income) for two or more } \\
\text { years in a net consecutive). }\end{array}$ & $\begin{array}{l}\text { companies which are categorical } \\
\text { variables, 0 for companies } \\
\text { experiencing financial distress and 1 } \\
\text { for healthy companies. }\end{array}$ \\
\hline Liquidity & $\begin{array}{l}\text { The ratio that describes the company's ability to } \\
\text { meet short-term obligations (debt) is the liquidity } \\
\text { ratio. [6] }\end{array}$ & \multicolumn{1}{c|}{$\begin{array}{l}\text { C urrent R a ti o }=\text { aktiva lancar } \\
\text { Kewiban Lancar }\end{array}$} \\
\hline Profitability & $\begin{array}{l}\text { This indicator is to assess the company's ability to } \\
\text { generate profits [8] }\end{array}$ & ROA = net income / Total Assets \\
\hline Financial Leverage & $\begin{array}{l}\text { This indicator is to measure the company's ability to } \\
\text { meet short-term and long-term obligations. [ }\end{array}$ & DER = Total Debt / Total Capital \\
\hline Operating Cash Flow & $\begin{array}{l}\text { Operating cash flow as determinant whether the } \\
\text { company's operations can generate cash that can be } \\
\text { used to pay off loans, maintain the company's } \\
\text { operating capabilities, pay dividends and make new } \\
\text { investments without relying on external funding } \\
\text { sources. }\end{array}$ & $\begin{array}{l}\text { CFFO net income + depreciation }+ \\
\text { debt + inventory. }\end{array}$ \\
\hline
\end{tabular}

Source: self-processed (2019)

Logit regression was used in this study as a test to determine the predictive power of financial ratios and financial ratios, which are the most dominant in determining whether a company will experience financial distress or not.

The models used in this study are:

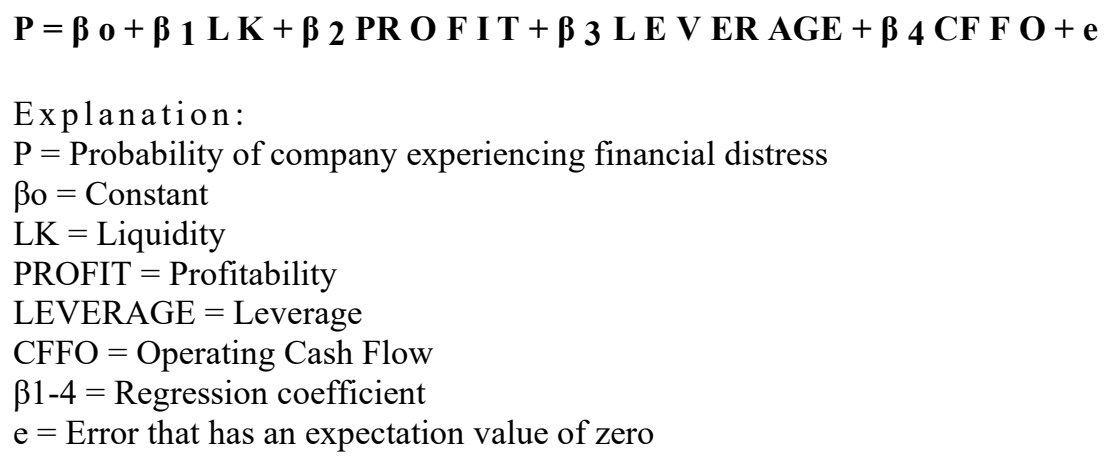

The step in conducting logistic regression analysis begins with analyzing descriptive statistics, which are descriptive or descriptive data (variables) that exist in this study. In this study, the descriptive statistics used are the average (mean), minimum and, standard deviation[4]. 


\section{Assessing the feasibility of the Regression Model (Model Fit)}

The output of Hosmer and Lemeshow's Goodness of fit test to assess the feasibility of the regression model. This test is to test the null hypothesis, empirical data fit or fits the model (there is no difference with the data) so that the model is declared fit. The value of goodness of fit test as measured by the chi-square value is shown in the following table of results:

a. If $\mathrm{p}$ value $>0.05$, then $\mathrm{H} 0$ is rejected and $\mathrm{Ha}$ is accepted

b. If $\mathrm{p}$-value $<0.05$ then $\mathrm{H} 0$ is accepted and $\mathrm{Ha}$ is rejected

\section{Assess the overall feasibility of the Model (Overall Model Fit)}

Assessing the overall feasibility of the model comes from the $-2 \log$-likelihood $(-2 \log L)$ statistical test output. This output has two values of $-2 \log L$, namely a model that only includes constants and a $-2 \log L$ model, the second by entering a constant and an independent variable. As for the assessment of the number - $2 \log L$ at the beginning or block number $=0$ and the number $-2 \log L$ at the block number $=1$. If there is a decrease of $-2 \log L$, then it shows a good logistic regression model for research. This testing is used to assess the model that has been hypothesized fit or not with data. the criteria according to (Ghozali, 2011) are as follows:

a. $\mathrm{H}_{0}(-2$ Initial $\log \mathrm{L}>-2$ Final $\log \mathrm{L})$ means that the hypothesized model is fit with the data.

b. Ha (-2 initial $\log \mathrm{L} \leq-2$ final $\log \mathrm{L})$ means that the hypothesized model is not fit with the data.

Log-likelihood in logistic regression is the same as the sum of squared error in the regression model so that the decrease in log-likelihood shows a good regression model.

\section{Value Nagelkerke's R Square}

Nagelkerke's $R$ Square is a modification of the Cox \& Snell's $R$ Square coefficient to ensure that its value varies from 0 to 1 . This is done by dividing the Cox \& Snell $R$ Square value by the maximum value. Value Nagelkerke's $R$ Square can be interpreted as the value of $R$ square in Multiple Regression [4].

\section{Result And Discussion}

Secondary data used in this study, namely the data obtained by researchers indirectly from the company. The data of this research are profitability (ROA), liquidity (CR), leverage (DER), operating cash flow, and financial distress. Samples were obtained from the Indonesia Stock Exchange website www.idx.co.id in the form of financial statements of companies on the Indonesia Stock Exchange.

The sample used in this study is a manufacturing company obtained from the Indonesia Stock Exchange during the 2015-2018 period. The purposive sampling method was used as sample selection based on predetermined criteria so that 21 companies were obtained for 5 years to obtain a research sample of 105 manufacturing companies.

Furthermore, testing includes analysis to assess the feasibility of the regression model ( model fit), assess the overall model fit ( overall model fit ), the value of Nagelkerke's $R$ square, and test the hypothesis.

\subsection{Assess the feasibility of the Regression Model}

The regression model feasibility assessment comes from the results of the Hosmer and Lemeshow's Goodness of fit Test. This test tests the null hypothesis, the data fit or fits the model (there is no difference) so that the model can be interpreted as fit. The goodness of fit test value as measured by the chi-square value can be seen from the results table below:

Table 4.1 Results of the Regression Model Feasibility Test

\begin{tabular}{cc|c|c}
\multicolumn{4}{c}{ Hosmer and Lemeshow Test } \\
Step & Chi-square & df & Sig. \\
\hline 1 & 3,239 & 8 &, 918 \\
\hline Source: spss output 21
\end{tabular}

Based on the table above. Unknown significance or value of the probability of accepting $\mathrm{H}_{0}$ for 0,918 which indicates a probability value $>0.05$ so that $\mathrm{H}_{0}$ is accepted or the model can be said to fit with the data. 


\subsection{Assess the Overall Feasibility of the Model}

Table 4. 2 Overall Model Feasibility Test Results Block 0: Beginning Block

\begin{tabular}{llr|r} 
& \multicolumn{3}{c}{ Iteration History $\mathbf{a , b}, \mathbf{c}$} \\
Iteration & & -2 Log likelihood & \multicolumn{1}{c}{$\begin{array}{c}\text { Coefficients } \\
\text { Constant }\end{array}$} \\
\hline Step 0 & 1 & 92,418 & 1,048 \\
\cline { 2 - 4 } & 2 & 92,211 & 1,160 \\
\cline { 2 - 4 } & 3 & 92,211 & 1,163 \\
\hline & 4 & 92,211 & 1,163 \\
\hline
\end{tabular}

Table 4. 2 Overall Model Feasibility Test Results Block 1: Method = Enter

\begin{tabular}{|c|c|c|c|c|c|c|c|}
\hline \multicolumn{8}{|c|}{ Iteration History ${ }^{\mathrm{a}, \mathrm{b}, \mathrm{c}, \mathrm{d}}$} \\
\hline \multirow{2}{*}{\multicolumn{2}{|c|}{ Iteration }} & & & & Coefficients & & \\
\hline & & -2 Log likelihood & Constant & LIQUIDITY & PROFITABILITY & LEVERAGE & $\begin{array}{l}\text { CASH FLOW } \\
\text { OPERATIONS }\end{array}$ \\
\hline \multirow{10}{*}{$\begin{array}{l}\text { Step } \\
1\end{array}$} & 1 & 59,976 &, 457 &, 160 & 5,246 & -244 &, 000 \\
\hline & 2 & 37,170 &, 769 &,- 003 & 19,659 & -420 &, 000 \\
\hline & 3 & 24,577 & 1,254 & -225 & 38,177 &,- 733 &, 000 \\
\hline & 4 & 18,688 & 1,822 &,- 467 & 59,661 & $-1,101$ &, 000 \\
\hline & 5 & 16,819 & 2,383 & -692 & 79,116 & $-1,426$ &, 000 \\
\hline & 6 & 16,481 & 2,697 & -830 & 91,457 & $-1,615$ &, 000 \\
\hline & 7 & 16,459 & 2,758 & -866 & 95,416 & $-1,665$ &, 000 \\
\hline & 8 & 16,458 & 2,759 &,- 868 & 95,801 & $-1,668$ &, 000 \\
\hline & 9 & 16,458 & 2,759 &,- 868 & 95,806 & $-1,668$ &, 000 \\
\hline & 10 & 16,458 & 2,759 &,- 868 & 95,806 & $-1,668$ &, 000 \\
\hline
\end{tabular}

Assessing the overall feasibility of the model comes from the statistical test output - 2 log-likelihood ($2 \log L$ ). The SPSS output gives two values - $2 \log L$, one for the model that only includes constants and the $2 \log L$ model, second by entering constants and independent variables. The assessment of $-2 \log L$ numbers at the beginning of block number $=0$ and $-2 \log L$ numbers at block number $=1$ if there is a decrease of $-2 \log L$ numbers, then it shows a good logistic regression model for research.

This test is used to assess the model that has been hypothesized fit or not with data. Based on table 4.2 for block 0 , with $\mathrm{N}=84$ then $\mathrm{N}-1=83$, the Chi-Square value is 105.267 . When compared with the chi-square value, the value of -2 Log-Likelihood $<$ Chi-Square table the result is $92.211<105.267$ Then the model is said to be fit and the logistic regression model is suitable for further analysis.

While overall it is known that the results show a decrease in the value of - $2 \log L$, namely from block number $=0$ of 92.418 to 59.976 in block number $=1$. Therefore, the conclusion is that the hypothesized model fits or following the data, so it can be used for research.

\subsection{Value of Nagelkerke's R Square}

Nagelkerke's $R$ Square is a modification of the Cox \& Snell's $R$ Square coefficient to ensure that its value varies from 0 to 1 . This is done by dividing the Cox \& Snell $R$ Square value by the maximum value. Value Nagelkerke's $R$ Square can be interpreted as the value of $R$ square in Multiple Regression (Ghoali, 2011).

Table 4. 3 Results of Nagelkerke's R Square

Summary Model

\begin{tabular}{rr|r|r}
\multicolumn{2}{c}{ Summary Model } \\
Step & -2 Log likelihood & $\begin{array}{c}\text { Cox \& Snell R } \\
\text { Square }\end{array}$ & \multicolumn{2}{c}{$\begin{array}{c}\text { Nagelkerke R } \\
\text { Square }\end{array}$} \\
\hline 1 & $16,458^{\text {a }}$ &, 594 &, 892 \\
\hline
\end{tabular}

Based on the data in table 4.4, Nagelkerke's $R$ Square value shown is 0.892 , which means the ability of the independent variable is $89.2 \%$ while the remaining $10.8 \%$ is influenced by other variables not discussed in this study. 


\subsection{Regression Coefficient Value}

This study examines the effect of liquidity, profitability, leverage, and cash flow operation to predict financial distress. Based on testing the regression coefficients in Table 4.5, the logistic equation model is obtained as follows:

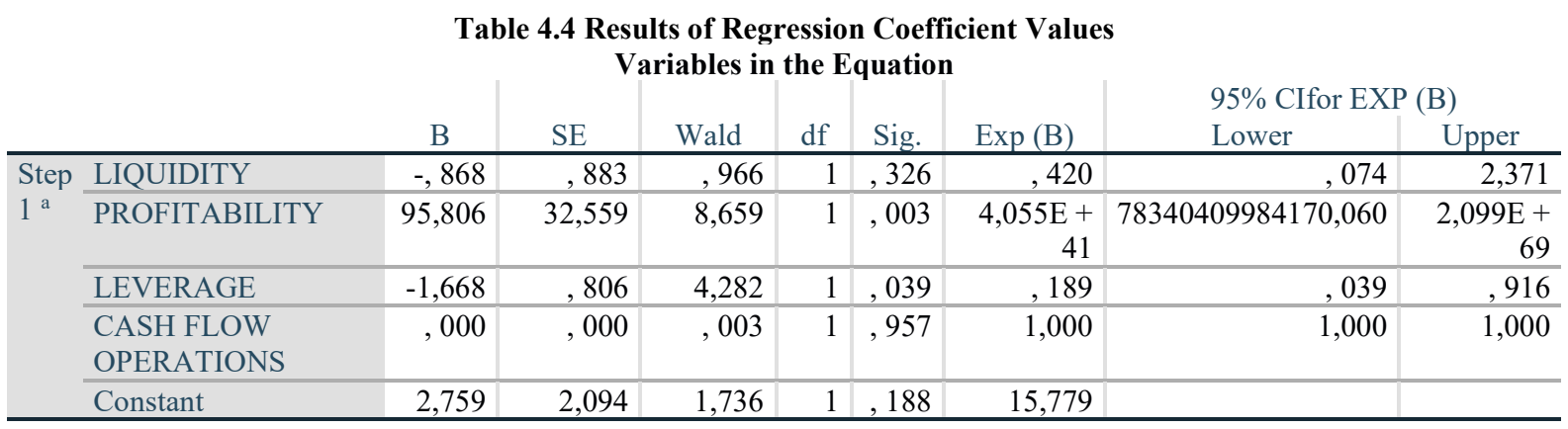

The results of the table above, the equation model is: $\mathrm{P}=2,759-0,868 \mathrm{LK}+95,806$ PROFIT $-1,668 \mathrm{LVRGE}+0,000 \mathrm{CFFO}+\mathrm{e}$

This model can be interpreted as follows:

$\alpha=2.75$ indicates that if liquidity, profitability, leverage, and operating cash flow, is equal to 0 , then it can predict financial distress.

$\beta 1=-0.868$ shows the regression coefficient of a negative liquidity ratio of -0.868 . This indicates that each increase in average Liquidity by $1 \%$, there will be a decrease in financial distress predictions of $86.8 \%$ with the assumption that the other variables are 0 .

$\beta 2=95.806$ shows the regression coefficient of a positive sign of the profitability ratio of 95.806 . This indicates that each increase in average profitability of $1 \%$, the prediction of financial distress will increase as well.

$\beta 3=-1.668$ shows the regression coefficient of a negative signed leverage ratio of -1.668 . This indicates that for each increase of an average of $1 \%$, there will be a decrease in the opportunity to predict a financial system of $16.68 \%$ with the assumption that other variables are 0 .

$\beta 4=0,000$ indicates the operating cash flow coefficient marked positive of 0,000 . This indicates that every time an increase in the company's operating cash flow will also increase the prediction of financial distress.

\subsection{Result and Discussion}

\subsubsection{Hypothesis Test Results}

Hypothesis testing can be done after a series of tests starting from assessing the feasibility of the model, evaluating Negelker's square, and obtaining the regression equation model used in the study. Hypothesis testing is done to see the ability of independent variables in the dependent variable. Hypothesis test results are shown in Table 4.5, that for testing hypothesis 1 that is the liquidity ratio (Current Ratio ) to the predict financial distress shows the value of wald $=0.966$ and the level of significance of $=0.326$ and means that the value is greater than 0.05 then $\mathrm{Ho}$ is accepted and $\mathrm{Ha}$ is rejected. This proves that there is no partial effect between the liquidity ratio variable with the prediction of financial distress.

The second Hypothesis Testing is the profitability ratio (Return on Assets ) to the prediction of financial distress shows a value of wald $=8.659$ and a significance level of $=0.003$ and means that the value is less than 0.05 then $\mathrm{Ho}$ is rejected and $\mathrm{Ha}$ is accepted. This proves that there is a partial effect between profitability ratio variables and financial distress prediction.

The third hypothesis testing is the leverage ratio ( Debt to Equity Ratio ) to the prediction of financial distress shows the value of wald $=4.282$ and the significance level of $=0.039$ and means that the value is less than 0.05 then $\mathrm{Ho}$ is rejected and $\mathrm{Ha}$ is accepted. This proves that there is a partial effect between the leverage ratio variable and the prediction of financial distress.

The fourth hypothesis testing, namely the operating cash flow ( $C F F O$ ) to the prediction of financial distress shows the value of Wald $=0.003$ and a significance level of $=0.957$ and means that the value is greater than 0.05 then Ho is accepted and $\mathrm{Ha}$ is rejected. This proves that there is no partial effect between operating cash flow variables with the prediction of financial distress. 


\subsubsection{Discussion}

The company's ability to meet its short-term obligations is called the liquidity ratio. The results of the test, the first hypothesis concluded that the liquidity ratio partially does not affect the prediction of financial distress. The significance value of these results is $0.326>0.05$. This means the size of the liquidity obtained will not affect the prediction of financial distress. The results of this study are following research conducted by [2], [1], [11] which stated that liquidity does not influence predicting financial distress. Liquidity is measured using a current ratio, which is a comparison between assets and short-term debt, so the higher the liquidity of a company, the smaller the risk of default on creditors so that collateral for the main creditor funds that have a relationship with the company's operations will also be high. However, this study is not following research [19] which states that liquidity influences in predicting financial distress.

For the second hypothesis testing, the profitability ratio is a measure to find out the level of profit of a company that is proxied by the Return on Assets (ROA) formula. logistic regression testing found that profitability has a positive and significant influence in predicting financial distress. Shown with a significance value $=0.003$ less than 0.05 so it can be interpreted that profitability is very important in predicting financial distress. This has indicated that the financial distress experienced by the company shows the use of ineffective assets which will ultimately affect the profits generated by the company. The results of this study are consistent with the results of the research conducted by [11].

For testing the third hypothesis, the leverage as measured by Debt to Equity (DER) is a ratio that measures how capital is compared with company debt, from logistic regression analysis shows that the significance level of 0.039 is less than 0.05 , meaning that the leverage influences in predicting conditions financial distress. The high level of corporate debt indicates that current assets in a company are unstable or declining so the company decides to make an external loan, if the debt is not well managed, it is likely to approach financial distress. The results of this study are consistent with the results of research conducted by [10], [15]. As for the last hypothesis, the company's operating cash flow does not have a significant influence in predicting financial distress. This result is consistent with that made by [2].

\section{Conclusion}

The results of research on the effect of liquidity ratios, profitability, leverage, and operating cash flow on financial distress predictions for the 2015-2018 period, it can be concluded that the results of testing the first hypothesis and the fourth hypothesis, testing the effect of liquidity variables and operating cash flow variables on a prediction of financial distress do not influence the prediction of financial distress. Meanwhile, the test results of two other variables, namely profitability and leverage, have a significant effect on the prediction of financial distress.

This study has results, there are still many limitations. Among these limitations include, this research period is not too long, and the object of this research is only in manufacturing companies that are included in the Indonesia Stock Exchange. The regression testing model is also quite simple, namely using logistic regression.

For further research, the researchers can add other variables to determine a greater influence on financial distress predictions, for example, the ratio used can use activity ratios or market ratios or maybe macroeconomic variables such as exchange rates (exchange rates), interest rates, and many more. Other macro factors that can be used, maybe even more interesting if you combine the micro and macroeconomic variables to see their effects on the company's financial distress. Meanwhile, the research sample can use the non-manufacturing sector with a long period so that it can give different results from previous research.

\section{References}

[1] Andre, Orina. dan Taqwa, Salma. 2014. Pengaruh Profitabilitas, Likuiditas Dan Leverage Dalam Memprediksi Financial Distress (Studi Empiris Pada Perusahaan Aneka Industri yang Terdaftar di BEI). Jurnal WRA. No.2 Vol. 1 April 2014.

[2] Arini, Diah. 2010. Analisis Rasio Keuangan Untuk Memprediksi Kondisi Financial Distress Perusahaan Manufaktur Yang Terdaftar Di Bursa Efek Jakarta. Skripsi thesis, Universitas Muhammadiyah Surakarta.

[3] Gailego, Gomes dan Yanes. 1997. Financial Distress and Corporate Governance: An Empirical Analysis. MCB University Press 1472-0701. Hal. 1523.

[4] Ghozali, Imam. 2002, Multivariate dengan Program SPSS, Badan Penerbit Universitas Diponegoro, Semarang.

[5] Gujarati, Damodar. 2003. Ekonometrika Dasar. Terjemahan Sumarno Zain. Jakarta: PT. Gelora Aksara Pratama.

[6] Hanafi, Mamduh M. dan Halim, Abdul. 2004. Analisis Laporan keuangan. STIM YKPN. Yogyakarta. 
[7] Husnan, Suad. 2015. Manajemen Keuangan. STIM YKPN. Yogyakarta

[8] Kasmir. 2010. Analisis Laporan Keuangan. PT. Rajawali: Jakarta.

[9] Luciana Spica Almilia, Kristijadi. 2003. Analisis Rasio Keuangan untuk Memprediksi Kondisi Financial Distress Perusahaan manufaktur yang terdaftar di BEJ. Jurnal Akuntansi dan Auditing Indonesia, Vol. 7 No. 2 Desember. Hal 183 - 206.

[10] Marfungatun. 2017. Pengaruh Rasio Profitabilitas, Likuiditas Dan Leverage Terhadap Kondisi Financial Distress Perusahaan Manufaktur Yang Terdaftar Di Bursa Efek Indonesia.

[11] Mas'ud, imam. Dan Srengga, Revi M. 2012. Analisis Rasio Keuangan Untuk Memprediksi Kondisi Financial Distress Perusahaan Manufaktur Yang Terdaftar Di Bursa Efek Indonesia. Jurnal Akuntansi Universitas Jember

[12] Platt, H and M. B. Platt. 2002. Predicting Financial Distress. Journal of Financial Service Professionals, 56.

[13] Prastowo, Dwi dan Rifka Juliaty. 2008. Analisis Laporan Keuangan: Konsep dan Aplikasi. Edisi Kedua. STIM YKPM: Yogyakarta.

[14] Prasetiono, 2011. Prediksi rasio keuangan terhadap kondisi financial distress perusahaan manufaktur yang terdaftar di BEI. Jurnal Dinamika dan Bisnis. Vol. 8 no.1 Maret 201.

[15] Saleh, Amir. dan Sudiyatno, Bambang. 2013. Pengaruh Rasio Keuangan Untuk Memprediksi Probabilitas Kebangkrutan Pada Perusahaan Manufaktur Yang Terdaftar Di Bursa Efek Indonesia. Dinamika Akuntansi, Keuangan dan Perbankan, Mei 2013, Hal: 82 - 91.

[16] Sugiyono. 2016. Statistika untuk Penelitian. Bandung: Alfabeta.

[17] Sutrisno. 2013. Manajemen Keuangan. Edisi 1. Yogyakarta: Ekonisia FakultasEkonomi UII.

[18] Widhiari, Ayu. dan Merkusiwati. 2015. Pengaruh Rasio Likuiditas, Leverage, Operating Capacity, Dan Sales Growth Terhadap Financial Distress. E-Jurnal Akuntansi Universitas Udayana 11.2 (2015): 456-469.

[19] Yustika. Kirmizi. Siti. 2015. Pengaruh Likuiditas, Profitablitias, leverage dan operating capacity dan Biaya Agensi Manajerial Terhadap Financial Distress. Jom FEKON, No 2 Vol 2. 